\title{
PERKEMBANGAN HUKUM ISLAM PADA MASA UMAR IBN KHATTAB (634-644 M)
}

\author{
Mami Nofrianti \\ Fakultas Syariah IAIN Batusangkar \\ Jl. Sudiman No. 137 Lima Kaum Batusangkar \\ e-mail: maminofrianti@iainbatusangkar.ac.id
}

\begin{abstract}
Islamic law is a law originating from and being part of the Islamic religion. Caliph Umar can be said to be the pioneer of legislation in an Islamic state. He has created a new paradigm in Islamic history. The development of Islam during the Caliph Umar to expand the Islamic region had a brilliant result. With the expansion of the Islamic region, the need for community education and fostering activities also increased. It was caused by people who had just converted to Islam in various conquered areas clearly needed guidance in the practice of Islamic application. Therefore, Islamic law had also undergone development from the previous period. The source of Islamic law in the era of Umar apart from the Qur'an and Sunnab was also carried out by Ijtibad. The method in this study was a library research, by collecting, reading, and studying books that have something to do with this discussion. At first glance Umar's decisions or Ijtibad seemed to contradict the provisions of the Qur'an, but if it was examined the nature of the verses in the framework of the overall purpose of Islamic law, the ijtihad carried out by Umar Ibn Khattab did not contradict with the meaning of the verses of the law.
\end{abstract}

Kata kunci: Hukum, Hukum Islam, Umar Ibn Khattab

\section{PENDAHULUAN}

P ada masa sahabat ijtihad belum bisa dikatakan sebagai alat penggali hukum karena ketetapan akhirnya tetap ada pada wahyu. Namun, pada masa tabi'in ijtihad benar-benar berfungsi sebagai alat penggali hukum, bahkan dipandang sebagai suatu kebutuhan yang harus dilakukan guna menyelesaikan berbagai kasus yang belum ada ketentuan hukumnya (Muhammad Amin, 1991: 29). Wilayah Islam pada masa ini telah meluas ke luar Jazirah Arab, seperti Mesir, Suriah, Persia, dan Irak sehingga para sahabat dihadapkan pada masalah-masalah baru yang belum ada ketentuan hukumnya.
Untungnya, di antara mereka telah terlatih sejak Nabi Muhammad Saw. masih hidup (Basiq Djalil, 2012: 139).

Abu Bakar biasa merujuk kepada kitab Allah saat memutuskan suatu hukum. Jika ketentuan hukum tidak terdapat dalam Alquran maka ia akan merujuk kepada sunnah Nabi. Jika ketentuan hukum tidak ditemukan juga maka ia akan mengundang para sahabat untuk bemusyawarah menetapkannya. Jika diperoleh kesepakatan maka keputusan perkara dengan kesepakatan tersebut. Umar ibn Khattab pun melakukan metode yang sama, bila tidak ditemukan suatu hukum di dalam Alquran dan Sunnah maka ia melihat 
apakah Abu Bakar pernah menetapkan hukumnya jika sudah maka ia mengikutinya. Namun jika belum, ia juga mengundang para sahabat untuk memutuskan hukum tersebut. Selain itu, dalam berijtihad Umar ibn Khattab sangat mempertimbangkan kemaslahatan umat ketimbang melihat zahir ayat sementara tujuan hukum tidak tercapai. Misalnya, penetapan Umar ibn Khattab mengenai tanah rampasan kepada para tentara. Jika tanah tersebut dirampas dari pemiliknya, mereka akan kehilangan mata pencaharian yang pada akhirnya menjadi beban negara. Tetapi, apabila mereka sendiri yang menggarapya dan membayar pajak pada negara, akan bermanfaat bagi negara. Selain mempertimbangkan kemaslahatan, Umar ibn Khattab juga menggunakan qiyas sebagai metode ijtihadnya. Para sahabat sangat berhatihati dalam menyatakan pendapat serta saling menghormati pendapat sesamanya. Misalnya, jika Abu Bakar berpendapat dan mengatakan, "Ini pendapatku, jika benar dari Allah dan jika ini salah dariku." Demikianlah halnya dengan Umar ibn Khattab dan Ibn Mas'ud. Karena kehatihatian itulah mereka hanya berijtihad atas sesuatu yang benar-benar terjadi, mereka tidak merefleksikan ketetapan suatu hukum yang belum terjadi (Basiq Djalil, 2012: 139).

Di kalangan para sahabat, yang paling terkenal banyak melakukan ijtihad adalah Umar ibn Khattab. Oleh karena itu dalam tulisan ini akan diuraikan bagaimana perkembangan hukum Islam pada masa Umar ibn Khattab berikut dengan contoh-contoh hasil ijtihad pada masa Umar dalam menetapkan hukum Islam.

\section{METODE PENELITIAN}

Adapun metode dalam penelitian ini adalah bercorak penelitian kepustakaan (library research), dengan mengumpulkan, membaca, dan menelaah buku-buku yang ada kaitannya dengan pembahasan ini. Sumber primer adalah Alquran yang berkaitan dengan konsep Hukum Islam dan buku-buku yang berkaitan dengan perkembangan Hukum Islam dan Peradaban Islam terutama pada masa Umar Ibn Khattab.

\section{PEMBAHASAN}

\section{Biografi Umar Ibn al Khattab}

Umar nama lengkapnya adalah Abu al Hafash 'Umar ibn al Khattab ibn Nufayl ibn 'Abd al 'Uzza ibn Rabbah ibn 'Abdillah ibn Qarth ibn Ramzah ibn 'Adiy ibn Ka'ab ibn Lu-ay al 'Adawiy, bertemu nasabnya dengan nabi Muhammad SAW dan Abu Bakr pada nenek moyang mereka Ka'ab ibn Lu-ay (Fatmawati, 2010: 124). Menurut Imam al-Thabariy, yang dikutip oleh (Hasan Ibrahim Hasan, 2002: 402). Umar dilahirkan di Makkah sekitar empat tahun sebelum terjadinya perang Fijjar, atau sekitar 13 tahun setelah kelahiran Muhammad SAW. Pada masa kecilnya, Umar menjadi penggembala ternak kepunyaan keluarganya dan pencari kayu api. Setelah dewasa, dia menjadi pedagang, namun harta dagangannya tidak begitu banyak.

Ketika Nabi mulai mengembangkan Islam di Makkah, 'Umar termasuk penentangnya yang paling keras. Umar memeluk Islam pada tahun keenam kenabian dan setelah memeluk Islam dia tampil 
sebagai pembela yang sejati. Sewaktu para sahabat yang lainnya hijrah ke Yastrib secara sembunyi-sembunyi, Umar malahan hijrah secara terangterangan dan menentang orang-orang Qurays, kalau ada yang berani menganggu perjalanannya. Menurut yang diriwayatkan oleh Ibn Atsir bahwa Abdullah ibnu Mas'ud berkata: Islamnya Umar adalah suatu kemenangan, Hijrahnya adalah suatu pertolongan, dan pemerintahannya adalah rahmat (Ahmad Syalabi, 2003: 203).

Setelah hijrah, Umar tetap menjadi pendamping setia Nabi Saw dan dia selalu diajak Nabi dalam setiap musyawarah. Banyak pendapat yang dikemukakan Umar yang kemudiannya dikuatkan oleh wahyu yang turun setelah itu (Fatmawati, 2010: 124).

Pada deretan Khulafaur Rasyidin, Umar adalah khalifah yang kedua dan dialah pertama kali diberi gelar Amir al-Mukminin sebelum Abu Bakar meninggal dunia. Ia mewasiatkan bahwa sepeninggal beliau nanti Umar lah yang menjadi khalifah dengan mengumpulkan penduduk di Mesjid Nabi saw, kemudian berkata kepada mereka: "Apakah kalian menyetujui orang yang kutunjuk untuk menggantikan Aku sepeninggalku? Sesungguhnya aku demi Allah telah bersungguh-sungguh berdaya upaya memikirkan hal itu, dan aku tidak mengangkat seseorang dari sanak keluarga tetapi aku telak menunjuk Umar ibn Kaththab sebagai penggantiku. Maka dengarlah dan taatilah ia. Orang banyak pun berkata
"Sami'na wa atha'na". Pengangkatan Umar menjadi Khalifah itu merupakan fenomena yang baru, tetapi haruslah dicatat bahwa proses peralihan kepemimpinan tetap dalam bentuk musyawarah, usulan, atau rekomendasi dari Abu Bakar yang diserahkan kepada persetujuan umat Islam (Asmal May, 2015: 75).

Begitu menjadi khalifah, Umar segera menghadapi tugas-tugas berat yang menjadi tanggungjawabnya, baik yang berhubungan dengan masalah dalam negeri (internal) maupun yang berkaitan dengan masalah luar negeri (eksternal) (Fatmawati, 2010: 127).

\section{Perkembangan Islam pada masa Umar Ibn Al Khathab}

Masa pemerintahan Umar Ibn Khattab yang lebih panjang dan selama 10 tahun (13-23 H / 634-644 M), tetapi dalam waktu yang relatif singkat Umar menunjukkan kesanggupan yang luar biasa yang tidak ada pada pemimpin Islam lainnya. Seluruh lapangan pemerintahan diisinya dengan sunahsunah yang baik untuk menjadi panutan atau ikutan orang-orang dibelakangnya (Michael H. Hart, 2005: 239). Pada masa Rasulullah pekerjaan yang terutama adalah menyampaikan agama Islam, dan mengajarkan kepada kaum Muslimin jalan-jalan untuk mencapai kebahagiaan dunia dan akhirat. Fungsi menyampaikan agama Islam telah dipenuhi oleh Rasulullah saw, dan telah dikerjakannya dengan baik. Juga fungsi menunjuki manusia kepada jalan untuk kebahagian bagi kaum Muslimin. Segala kesulitankesulitan yang mereka temui telah 
dapat diatasi dan dipecahkan oleh Nabi. Hanya saja di masa Nabi masih hidup agama Islam belum lagi melampaui Jazirah Arab, dan kehidupan bangsa Arab pun masih sederhana dan bersahaja. Tetapi tatkala agama Islam telah meluas ke Syam, Mesir, dan Persia, agama Islam menjumpai kebudayaan yang hidup di negeri-negeri tersebut. Islam telah berhadapan dengan keadaan-keadaan baru, dan timbullah berbagai macam kesulitan dan soal-soal yang belum pernah dikenal dan dijumpai oleh kaum Muslimin selama ini (Ahmad Syalabi, 2003: 225).

Di masa pemerintahan Abu Bakar kesulitan-kesulitan ini belum lagi timbul, karena masa beliau adalah amat singkat. Beliau berpulang ke rahmatullah di waktu peperanganpeperangan antara kamu Muslimin dengan bangsa Persia dan Rumawi baru dimulai dan belum dapat diselesaikan. Jadi kemenangan kaum Muslimin belum lagi sempurna. Persoalan-persoalan dan kesulitan datangnya di masa Khalaifah Umar ibn Khattab. Maka di atas pundaknyalah terletak beban untuk mengatasi dan memecahkannya. Tuhan telah memberi ilham dan taufik kepada Umar dalam memperkenankan panggilan zaman, menjawab tantangan hidup baru, dan membangun negara Islam.

Dalam masa kepemimpinan Umar yang sepuluh tahun itu, penaklukanpenaklukan penting dilakukan oleh umat Islam. Tidak lama sesudah Umar menduduki kekuasaan sebagai khalifah, pasukan Arab menduduki Suriah dan Palestina, yang saat itu menjadi bagian kekaisaran Byzantium.
Dalam pertempuran Yarmuk (636 M) Pasukan Arab berhasil memukul kekuatan Byzantium. Damaskus jatuh pada tahun itu juga, Yerussalem menyerah dua tahun kemudian. Menjelang tahun 641 M, Pasukan Arab telah menguasai seluruh Palestina dan Suriah, dan terus menerjang maju ke daerah yang kini bernama Turki. Tahun 639 M, Pasukan Arab menyerbu Mesir yang saat itu juga di bawah kekuasaan Byzantium. Dalam waktu tiga tahun penaklukan Mesir diselesaikan dengan sempurna (Asmal May, 2015: 78).

Penyerangan Arab terhadap Irak yang saat itu berada di bawah kekuasaan Kekaisaran Persia telah dimulai bahkan sebelum Umar menjabat menjadi khalifah. Kunci kemenangan Arab terletak pada pertempuran Qadisiyah tahun $637 \mathrm{M}$, terjadi pada kekhalifahan Umar. Menjelang tahun $641 \mathrm{M}$, seluruh Irak sudah berada di bawah pengawasan Arab, bukan hanya itu pasukan Arab bahkan menyerbu langsung Persia dan dalam pertempuran Nehavend (642 M) mereka mengalahkan sisa terakhir kekuatan Persia. Menjelang wafatnya Umar pada tahun $644 \mathrm{M}$, sebagian besar daerah barat Iran sudah terkuasai sepenuhnya. Gerakan ini tidak berhenti sampai wafatnya Umar. Di bagian Timur, mereka dengan cepat menaklukan Persia dan bagian Barat mereka mendesak terus dengan pasukan menyeberang Afrika Utara (Michael H. Hart, 2005: 239).

Pada mulanya khalifah Umar melarang para sahabat utama untuk keluar dari Madinah, kecuali atas izin khalifah dan dalam waktu yang terbatas, sehingga ilmu dan 
pengetahuan para sahabat itu berpusat di Madinah. Karena itu, setiap orang yang akan mendalami ilmu agama harus pergi ke Madinah untuk belajar kepada para sahabat., bahkan Khalifah Umar sendiri menjadi salah seorang guru di Masjid Madinah. Namun dengan meluasnya wilayah kekuasaan Islam ke luar Jazirah Arabia, Khalifah Umar merubah kebijaksanaannya itu. Kegiatan pendidikan tidak bisa lagi dipusatkan di Madinah saja, tetapi juga harus dilaksanakan di daerah-daerah yang baru ditaklukan itu. Karena itu, beliau memerintahkan kepada para panglima perangnya supaya mendirikan masjid di tiap kota yang mereka taklukkan sebagai tempat ibadah dan pendidikan (Asrohah, 2001: 17). Khalifah kemudian mengirim para sahabat untuk menjadi guru di masjidmasjid tersebut, seperti 'Abdullah ibn Mas'ud yang dikirim ke Kufah, 'Abd al Rahman ibn Ma'qal dan 'Imran ibn al Hushaun yang dikirim ke Bashrah, 'abd al Rahman ibn Ghanam yang dikirim ke Syiria, Hasan ibn Abi Jabalah yang dikirim ke Mesir, dan lain-lainnya (Fatmawati, 2010: 136-137).

Dengan meluasnya wilayah kekuasaan Islam, kegiatan pendidikan Islam juga menjadi semakin meningkat, karena mereka yang baru masuk Islam itu ingin menimba ilmu keagamaan dari para sahabat yang menerima langsung dari Nabi Saw. Pada masa ini semangat dan kegiatan menuntut ilmu sangat tinggi, mereka relah meninggalkan kampung halamannya untuk datang ke Madinah menuntut ilmu pengetahuan. Gairah menuntut ilmu ini sekaligus juga mendorong lahirnya pembidangan disiplin ilmu keagamaan.

Khalifah Umar dapat dikatakan sebagai pelopor perundang-undangan dalam negara Islam. Beliau telah membuka lembaran baru dalam Sejarah Islam, membentuk pemerintahan, menyusun dewan-dewan negara, mengatur peradilan dan administrasi, menyempurnakan Bayt al Mal, memperlancar komunikasi antar berbagai daerah dengan membuat dewan pos. Dengan kata lain, beliau meletakkan dasar-dasar dalam setiap perundang-undangan yang dapat dijadikan sebagai panutan bagi masamasa selanjutnya. Sebagai contoh adalah azas musyawarah yang telah dipraktekkan oleh Umar dalam pemerintahannya. Beliau mengumpulkan para sahabat yang ahli dalam berbagai bidang untuk bermusyawarah dalam mengambil suatu keputusan atau mengeluarkan fatwa. Para sahabat ini sengaja tidak ditugaskan ke luar Madinah karena mereka diharapkan dapat memberikan pendapat ataupun dukungan dan bantuan pemikiran kepada khalifah Umar (Fatmawati, 2010: 143-144).

Umar adalah orang yang pertama mencetuskan ide perlunya dilakukan pengumpulan ayat-ayat Alquran. Ketika itu ayat-ayat Alquran tersebar di berbagai lempengan batu, pelepah kurma, tulang belulang dan sebagainya. Tempatnya pun berserakan di tangan para sahabat, tidak terkumpul dalam satu tempat. Pada masa Nabi Muhammad Saw, cukup banyak sahabat yang menghafal Alquran seluruhnya, sehingga 
mengumpulkan tulisan-tulisan Alquran belum dirasa perlu. Akan tetapi, pada masa Khalifah Abu Bakar terjadi banyak peperangan yang di dalamnya gugur banyak sahabat penghafal Alquran dalam perang Yamamah saja 70 orang penghafal Alquran yang gugur. Oleh karena itu, Umar khawatir para penghafal Alquran akan habis. Dengan alasan itu, Umar mengusulkan kepada Abu Bakar, agar segera dikumpulkan semua tulisan ayat-ayat Alquran. Pada mulanya Abu Bakar keberatan menerima usulan Umar, karena nabi Saw, tidak pernah melakukan hal serupa, namun atas desakan Umar usul itupun disetujuinya. Abu Bakar lalu mempercayakan tugas pengumpulan itu kepada Zaid ibn Tsabit, penulis wahyu pada masa Rasulullah Saw (Asmal May, 2015: 79).

Demikianlah perkembangan Islam pada masa Khalifah Umar, usaha perluasan wilayah Islam pada masa Umar memperoleh hasil yang gemilang. Wilayah Islam pada masa ini meliputi seluruh Semenanjung Arabia, Syiria, Persia dan Mesir di Afrika Utara. Dengan meluasnya wilayah Islam, maka kebutuhan terhadap kegiatan pendidikan dan pembinaan umat juga menjadi meningkat. Sebab, orang-orang yang baru masuk Islam di berbagai daerah taklukan itu jelas memerlukan bimbingan dan pembinaan dalam pengamalan ajaran Islam.

\section{Perkembangan Hukum Islam pada masa Umar Ibn Al Khattab}

Dengan wafatnya Nabi Muhammad, berhentilah wahyu yang turun selama 22 tahun 2 bulan 22 hari yang beliau terima melalui Malaikat Jibril baik waktu beliau masih berada di Makkah maupun setelah hijrah ke Madinah. Demikian juga halnya dengan sunnah, berakhir pula dengan meninggalnya Rasulullah itu (Mohammad Daud Ali, 2011: 169).

Kedudukan nabi Muhammad sebagai utusan Tuhan tidak munkin diganti tetapi tugas beliau sebagai pemimpin masyarakat Islam dan kepala negara harus dilanjutkan oleh orang lain. Pengganti nabi Muhammad sebagai kepala negara dan pemimpin umat Islam ini disebut Khalifah, suatu kata yang "dipinjam" dari Alqur'an (surat 2: 30). Kata khalifah yang terdapat dalam Alqur'an, terutama kata khalifah yang terdapat dalam ayat yang berhubungan dengan pengangkatan Adam menjadi khalifah (Tuhan) di muka bumi ini dipinjam dan dijadikan gelar bagi orang yang menggantikan kedudukan Nabi Muhammad sebagai pemimpin ummat Islam dan kepala negara (Mohammad Daud Ali, 2011: 170).

Tugas utama seorang khalifah adalah menjaga kesatuan umat dan pertahanan negara. Untuk itu khalifah mempunyai hak-hak tertentu, ia berhak memaklumkan perang dan membangun tentara untuk menjaga keamanan dan batas negara. Ia harus menegakkan keadilan dan kebenaran dan berusaha agar semua lembagalembaga negara memisahkan antara yang baik dengan yang tidak baik, melarang hal-hal yang tercela menurut ketentuan Alqur'an. Khalifah mengawasi jalannya pemerintahan dan menarik pajak sebagai sumber 


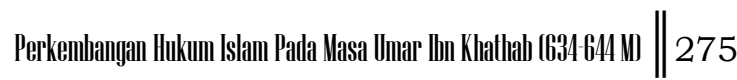

keuangan negara. Ia menjadi hakim yang mengadili sengketa hukum, menghukum mereka yang melanggar hukum dan melarang segala macam penindasan. Ia mensahkan soal-soal akidah dan hukum yang sudah disepakati oleh ahli-ahli hukum (Mohammad Daud Ali, 2011: 170).

Kata Hukum Islam tidak ditemukan sama sekali di dalam Alquran dan literatur hukum dalam Islam, yang ada dalam Alquran adalah kata Syari'ah, fiqh, hukum Allah dan yang seakar dengannya. Atau yang biasa digunakan dalam literatur hukum dalam Islam adalah Syari'at Islam, fiqh Islam dan Hukum Syara' (Fathurrahman Djamil, 1997: 8). Dengan demikian kata Hukum Islam merupakan istilah Khas Indonesia yang agaknya diterjemahkan secara harfiyah dari term Islamic Law dari literatur Barat. Adapun defenisi dari Hukum Islam itu sendiri setidaknya ada dua pendapat yang berbeda di kalangan para ulama dan ahli Hukum Islam di Indonesia. Hasby ash-Shidieqy dalam bukunya Falsafah Hukum Islam memberikan defenisi Hukum Islam dengan "Koleksi daya upaya fuqaha dalam menerapkan syari'at Islam sesuai dengan kebutuhan masyarakat" (Hasbi, 1993: 44).

Sementara itu Amir Syarifuddin memberikan penjelasan bahwa apabila kata Hukum dihubungkan dengan Islam, maka Hukum Islam berarti: Seperangkat peraturan berdasarkan Wahyu Allah dan sunnah Rasul tentang tingkah laku manusia mukallaf yang diakui dan diyakini berlaku dan mengikat untuk semua umat yang beragama Islam. Secara sederhana dapat dikatakan bahwa Hukum Islam adalah Hukum yang berdasarkan Wahyu Allah. Sehingga hukum Islam menurut ta'rif ini mencakup Hukum Syari'ah dan Hukum Figh, karena arti syara' dan fiqh terkandung di dalamnya (Amir Syarifuddin, 1990: 19).

Perbedaan defenisi Hukum Islam yang telah dikemukakan oleh kedua ahli Hukum Islam di atas, sesungguhnya dapat dipahami bahwa perbedaan itu hanya terletak pada cakupan yang dilingkupinya. Pendapat yang pertama membatasi pengertian Hukum Islam hanya pada makna fiqh. Sedangkan pendapat yang kedua Hukum Islam pengertiannya bisa dimaksudkan pada makna sayri'ah dan kadangkala bukan pada substansinya, apalagi ketika dikaitkan dengan kemungkinan bisa dan tidaknya Hukum Islam itu berubah dan diubah.

Berdasarkan uraian di atas jelaslah bahwa kalau ada yang mengatakan bahwa Hukum Islam itu tidak berubah dan tetap maka yang dimaksudkan dengan kata Hukum Islam di sini adalah bermakna syari'ah atau hukum syara'. Yakni ajaran Allah yang kebenarannya bersifat mutlak dan telah lengkap serta sempurna. Jika dikatakan bahwa Hukum Islam itu berubah dan dapat dikontekstualisasikan sesuai dengan perkembangan dan perubahan zaman, maka itu merupakan Hukum Islam bermakna Fiqh, sebagai hasil ijtihad dan interpretasi manusia (mujtahid) terhadap ajaran syari'ah yang kebenarannya bersifat relatif (Abdul Halim Barkatullah, 2006: 3-4). 
Setelah Khalifah pertama Abu Bakar as Siddiq meninggal dunia, Umar menggantikan kedudukannya sebagai khalifah kedua. Pemerintahan Umar ibn Khattab ini berlangsung selama 10 tahun yakni dari tahun 634 644 M. Satu hal yang perlu dicatat terlebih dahulu tentang kebijakankebijakan Umar dalam melanjutkan usaha pendahulunya adalah: (1) Umar turut aktif dalam menyiarkan agama Islam. Ia melanjutkan usaha Abu Bakar meluaskan daerah Islam sampai ke Palestina, Syiria, Irak, dan Persia di sebelah Utara serta ke Mesir di Barat Daya, (2) menetapkan tahun Islam yang terkenal dengan tahun Hijriah berdasarkan peredaran bulan (qamariyah), dibandingkan dengan tahun Masehi (Miladiyah) yang didasarkan pada peredaran matahari. Perbedaan di antara tahun ini setiap tahun adalah 11 hari. Penetapan tahun Hijriah ini dilakukan Umar pada 638 M, (3) Sikap tolerannya terhadap pemeluk agama lain. Hal ini terbukti ketika belaiu hendak mendirikan masjid di Jerussalem (Palestina). Beliau minta izin kepada pemuka agama lain di sana, padahal beliau adalah pemimpin dunia waktu itu (Mohammad Daud Ali, 2011: 175).

Ketika Islam semakin tersebar, masalah hukum semakin bertambah dan semakin meluas pula peranan para gubernur. Oleh karena itu Umar Ibn Khattab memisahkan peradilan (yudikatif) dari pemerintahan (eksekutif), dan mengangkat beberapa orang sebagai hakim selain para gubernur. Umar mengangkat Abu Darda' sebagai hakim di Madinah, Syuraih sebagai hakim di Bashrah, dan Abu Musa al-
Asy'ari sebagai hakim di Kufah (Alaiddin Koto 2011). Umar melakukan hal yang sama dengan Abu Bakar. Sebelum mengumpulkan sahabat untuk bermusyawarah, ia bertanya kepada sahabat lain: "Apakah kalian mengetahui bahwa Abu Bakar telah memutuskan kasus yang sama?" Jika pernah, ia mengikuti kepetusan itu. Jika tidak ada, ia mengumpulkan sahabat dan bermusyawarah untuk menyelesaikannya. Sebagaimana yang dikutib dari (Umar Sulaiman AlAsyqar, 1991: 75). Salah satu wasiat Umar ra. kepada qadhi (hakim) pada zamannya, yaitu Syuraih. Wasiat tersebut adalah:

a. Berpeganglah kepada Alquran dalam menyelesaikan kasus

b. Apabila tidak ditemukan dalam Alquran, hendaklah engkau berpegang kepada sunnah

c. Apabila tidak didapatkan ketentuannya dalam sunnah, berijtihadlah (Jaih Mubarok, 2000: 40).

Kepada Abu Musa al-Asy'ari, Umar pernah berpesan yang isinya mengandung pokok-pokok penyelesaian perkara di muka sidang, yang ternyata disambut dan diterima di kalangan Ulama serta dihimpunlah daripadanya pokok-pokok hukum. Isi suratnya sebagai berikut:

“Amma ba'du. Sesungguhnya memutuskan perkara adalah fardhu yang dikokohkan dan sunnah yang harus diikuti. Lalu pahamilah apabila diajukan kepadamu (suatu perkara), dan putuskanlah apabila telah jelas (kedudukannya), karena sebenarnya tidaklah ada artinya 
bicara soal keadilan tanpa ada pelaksanaannya. Sama ratakanlah manusia (pihak-pihak yang berpekara) dalam majelismu, dalam pandanganmu, dan dalam keputusanmu, sehingga orang yang berpangkat tidak akan mengharapkan penyelewenganmu, dan orang yang lemah tidak sampai putus asa mendambakan keadilanmu. Bukti itu wajib atas pihak yang menolak (gugatan/ tuduhan). Dan boleh mengadakan perdamaian di antara kaum Muslim, kecuali perdamaian yang menghalalkan yang haram dan mengaharamkan yang halal. Barangsiapa yang mendakwakan sesuatu hak yang tiada ada di tempatnya, atau di suatu bukti, maka berilah tempo kepadanya sampai ia dapat membuktikan dakwaannya, kemudian kalau ia dapat membuktikannya, maka berikanlah haknya itu, tetapi kalau ia tidak mapu membuktikannya, karena yang demikian itu lebih mantap bagi keuzurannya dan lebih menampakkan barang yang tersembunyi. Janganlah sekali-kali menghalangi kepadamu, sesuatu keputusan yang telah engkau jatuhkan hari ini, kemudian engkau tinjau kembali, lalu engkau memperoleh petunjuk agar engkau kembali kepada kebenaran, karena sesungguhnya kebenaran itu harus didahulukan, tidak dapat dibatalkan oleh apa pun, sedangkan kembali kepada kebenaran itu lebih baik dari pada terus bergelimang dalam kebatilan. Orang-orang Islam itu dianggap adil sebagian mereka terhadap sebagian yang lain, kecuali orang yang pernah memberikan kesaksian palsu atau orang yang pernah dijatuhi hukuman had, atau orang yang diragukan tentang asalusulnya, karena sesungguhnya Allah yang mengetahui rahasia-rahasia manusia dan menghindarkan hukuman atas mereka. Kecuali dengan adanya bukti-bukti atau sumpah-sumpah. Kemudian pahamilah dengan sungguhsungguh tentang perkara yang diajukan kepadamu, yang tidak terdapat ketentuan hukumnya di dalam Alquran dan tidak terdapat pula dalam Sunnah Nabi Muhammad Saw, kemudian bandingkan perkara-perkara itu, dan perhatikannlah perkara yang serupa hukumnya dengan perkara-perkara itu, kemudian pegangilah mana hukum yang menurut pendapatmu lebih diridhai Allah dan lebih mendekati kebenaran. Hindarkanlah dirimu dari marah, pikiran yang kacau, rasa jemu, menyakiti orang yang berpekara, dan bersikap keras pada waktu menghadapi mereka, karena memutus perkara di tempat yang benar adalah termasuk pekerjaan yang dipahalai Allah dan membawa nama baik. Maka barang siapa memurnikan niatnya demi mencari kebenaran, walaupun merugikan diri sendiri, maka Allah akan memberinya kecukupan, dan barangsiapa berlagak memiliki keahlian yang tidak ada pada dirinya, maka pasti Allah akan membuka rahasia kejelekannya itu, 
karena sesungguhnya Allah tidak akan menerima amal dari hambaNya kecuali amal yanga didasari dengan ikhlas, lalu bagaimanakah persangkaanmu tentang pahala dari Allah, baik yang akan segera di berikan maupun yang ada di dalam perbendaharaan rahmat-Nya." (Alaiddin Koto, 2011: 64-66).

Para hakim pada masa Umar merujuk kepada Alquran. Jika tidak mendapati hukum dalam Alquran mereka mencarinya dalam sunnah. Tapi jika mereka tidak mendapatkan sesuatu di dalamnya, mereka bertanya kepada fuqaha mujtahidin, apakah di antara mereka terdapat orang yang mengerti sesuatu dalam Sunnah mengenai perkara yang dihadapi. Jika didapatkan, mereka berpedoman dengan apa yang dikatakan orang yang mengetahuinya tersebut setelah dilakukan upaya penguatan. Jika tidak didapatkan, mereka berijtihad secara kolektif jika topik permasalahan terdapat hubungan dengan prinsipprinsip dasar jamaah, dan berijtihad secara invidu dalam masalah-masalah sektoral yang khusus dengan individu (Alaiddin Koto, 2011: 66).

Berikut ini adalah sebagian contoh kasus peradilan pada masa Umar ibn Khaththab, yaitu:

a. Masalah nasab

Seorang anak mengaku di depan Umar bahwa seorang wanita adalah ibunya. Maka, wanita tersebut datang dengan beberapa orang yang bersaksi bahwa dia belum menikah dan anak tersebut telah berbohong. Umar pun memerintahkan untuk menghukumnya dengan had qazaf (tuduhan zina). Lalu, hal tersebut terdengar oleh Ali, maka dia mengintervensi perkara ini dan menawarkan kepada anak tersebut agar menikahi wanita yang diakui sebagai ibunya. Wanita itupun berteriak:" Allah, Allah, itu neraka. Demi Allah, dia adalah anakku". Kemudian dia mengakui bahwa keluarganya telah menikahinya dengan seorang tanpa kerelaannya, lalu ia mengandung anak ini darinya, dan suaminya pergi berperang lalu terbunuh. Kemudian dia mengirimkan anaknya kepada kaum yang bersedia merawatnya, dan tidak mengakuinya sebagai anak. Maka, Ali menetapkan nasab anak tersebut dengan wanita yang ditunjukinya (Samir 'Aliyah 2004).

b. Masalah makar perempuan

Seorang perempuan sangat tertarik kepada seorang pemuda, maka dia menuangkan zat putih pada bajunya dan di antara dua pahanya. Lalu perempuan itu mengadu kepada Umar ibn Khattab dengan mengatakan bahwa pemuda tersebut memperkosanya seraya mengisyaratkan bekas-bekas yang dibuatnya. Pemuda itupun menolak dakwaan tersebut, dan Umar mengalihkan masalah ini kepada Imam Ali. Ali memerintahkan untuk diambilkan air panas lalu dituangkan pada baju, dan mengeraslah zat yang putih tersebut, sehingga tampak jelas letak kebenaran sebab kecerdasan Ali dan kecermatan pandangannya. Demikianlah bentuk penyelesaian secara kimiawi. Akhirnya, Imam Ali 
bertanya kepada wanita tersebut dan dia mengakui rekayasanya sehingga tuduhannya tersebut ditolak.

Di antara hakim di masa Umar adalah Abu Maryam Iyas bin Shabih alHanafi, yang diangkat sebagai hakim di Bashrah, kemudian dipecat berdasarkan laporan masyarakat tentang kelemahannya. Pemecatan itu disebabkan bahwa Umar mendengar ketika Abu Maryam sedang menyelesaikan perselisihan dua orang tentang satu dinar, maka Abu Maryam mendamaikan keduanya dengan menyerahkan dinar dari uangnya sendiri. Maka Umar menulis surat kepadanya, "Sesungguhnya saya tidak menugaskan kamu untuk memutuskan hukum di antara manusia dengan uang kamu. Tapi saya menugaskan kamu agar kamu memutuskan di antara mereka dengan kebenaran" (Alaiddin Koto, 2011: 63).

Karena usianya yang relatif masih muda dibandingkan dengan Abu Bakar, Umar lama memegang pemerintahan. Sifatnya keras dan sebagaimana biasanya, orang yang mempunyai sifat keras selalu berusaha bertindak adil melaksanakan hukum. Terkenal keberaniannya dalam menafsirkan ayat-ayat Alquran berdasarkan keadaan-keadaan yang nyata pada suatu waktu tertentu. Ia mengikuti cara Abu Bakar dalam menemukan hukum. Namun demikian, Khalifah Umar terkenal keberanian dan kebijaksanaannya dalam menerapkan ketentuan hukum yang terdapat dalam Alquran untuk mengatasi sesuatu masalah yang timbul dalam masyarakat berdasarkan kemaslahatan atau kepentingan umum.

Sepintas lalu keputusankeputusan (dalam kepustakan terkenal dengan Ijtihad) Umar itu seakan-akan bertentangan dengan ketentuanketentuan Alquran, namun kalau dikaji sifat hakikat ayat-ayat tersebut dalam kerangka tujuan hukum Islam keseluruhannya, ijtihad yang dilakukan oleh Umar Ibn Khattab itu tidak bertentangan dengan maksud ayat-ayat hukum tersebut.

Banyak tindakan Umar di lapangan hukum, namun yang akan dikemukakan adalah beberapa contoh ijtihad Umar, yakni:

a. Talak tiga yang diucapkan sekaligus di suatu tempat pada suatu ketika, dianggap sebagai talak yang tidak mungkin rujuk (kembali) sabagai suami-istri, kecuali salah satu pihak (dalam hal ini bekas istri) kawin lebih dahulu dengan orang lain. Garis hukum ditentukan oleh Umar berdasarkan kepentingan para wanita, karena di zamannya banyak pria yang dengan muda mengucapkan talak tiga sekaligus kepada istrinya, untuk dapat bercerai dan kawin lagi dengan wanita lain. Tujuannya adalah untuk melindungi kaum wanita dari penyalahgunaan hak talak yang berada di tangan pria. Tindakan ini dilakukan oleh Umar agar pria berhati-hati mempergunakan hak talak itu dan tidak muda mengucapkan talak tiga sekaligus yang di zaman nabi dan Khalifah Abu Bakar dianggap (jatuh sebagai) talak satu. Umar menetapkan garis 
hukum yang demikian, untuk mendidik suami supaya tidak menyalahgunakan wewenang yang berada dalam tangannya.

b. Alquran telah menetapkan golongan-golongan yang berhak menerima zakat, termasuk muallaf di dalamnya yaitu (di antaranya orangorang yang baru memeluk agama Islam yang seyogianya dilindungi karena masih lemah imannya dan karena ia memeluk agama Islam hubungannnya dengan keluarganya (mungkin) terputus. Pada zaman Rasulullah golongan ini memperoleh bagian zakat, tetapi Khalifah Umar menghentikan pemberian zakat kepada muallaf berdasarkan pertimbangan bahwa Islam telah kuat, umat Islam telah banyak sehingga tidak perlu lagi diberikan keistimewaan kepada golongan khusus dalam tubuh umat Islam.

c. Menurut Alquran surat Al-Maidah (5) ayat 38 orang yang mencuri diancam dengan hukuman potong tangan. Di masa pemerintahan Umar terjadi kelaparan dalam masyarakat di Semenanjung Arabia. Dalam keadaan masyarakat ditimpa oleh bahaya kelaparan itu, ancaman hukuman terhadap pencuri yang disebut dalam Alquran tidak dilaksanakan oleh Khalifah Umar berdasarkan pertimbangan keadaan (darurat) dan kemaslahatan (jiwa) masyarakat.

d. Di dalam Alquran (QS 5: 5) terdapat ketentuan yang membolehkan pria Muslim menikahi wanita ahlul kitab (wanita Yahudi dan Nasrani). Akan tetapi Khalifah Umar melarang perkawinan campuran demikian, untuk melindungi kedudukan wanita Islam dan keamanan (rahasia) negara (Mohammad Daud Ali, 2011: 175-177).

e. Pada masa pemerintahan Abu Bakar, Umar ibn Khattab menyatakan pendapat yang berbeda dengan $\mathrm{Abu}$ Bakar yang menyamaratakan harta rampasan di kalangan Muhajirin dan Anshar. Ketika masa pemerintahannya, ia membagikan harta rampasan berdasarkan prestasi Muhajirin dan Anshar.

f. Umar ibn Khattab menetapkan untuk tidak membagikan harta rampasan perang kepada para tentara yang berjasa merebutnya. Namun, tanah rampasan tersebut tetap digarap oleh pemiliknya dan mereka dikenakan pajak untuk kepentingan negara (Basiq Djalil, 2012: 142).

g. Umar ibn Khattab berfatwa tentang masa iddah seorang istri yang dicerai sebelum monopause, namun tidak menstruasi sebelum dicerai. Masa iddahnya adalah sembilan bulan (masa hamil), jika memang hamil maka itulah masa iddahnya. Jika tidak maka masa iddahnya ditambah tiga bulan untuk menentukan atau meyakinkan kebersihan rahim.

h. Umar ibn Khattab memerintahkan bercerai kepada laki-laki yang menikahi perempuan yang masih dalam masa iddah dan bercampur dengannya. Seorang istri harus menyelesaikan masa iddah dengan suaminya yang pertama dan ditambah iddah suami yang kedua. Setelah itu, keduanya tidak boleh saling menikah. Umar ibn Khattab 


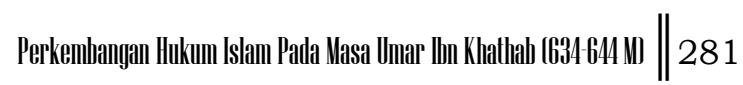

menqiyaskan larangan tersebut dengan pembunuhan yang dilakukan oleh ahli waris. Keduanya terdapat kesamaan, yaitu keinginan mengambil hak sebelum waktunya sehingga hukumannya adalah terhapusnya hak si pelanggar untuk menikahi atau mewarisi. Pendapat Umar ibn Khattab ini berbeda dengan Ali ibn Abi Thalib yang membolehkan pria menikahi wanita tersebut setelah selesai kedua masa iddahnya. Ketetapan Umar tersebut tidak ada nashnya, namun ia melakukannya untuk tindakan preventif agar umat Islam tidak mudah melakukan pelanggaran.

i. Tentang pembunuhan yang dilakukan oleh orang banyak. Atas saran Ali ibn Abi Thalib, Umar Ibn Khattab memutuskan untuk menghukum semua yang terlibat dalam pembunuhan tersebut seperti halnya persengkokolan dalam pencurian. Maka semuanya yang bersekongkol dikenakan hukuman potong tangan.

j. Tentang unta yang hilang. Umar ibn Khattab memutuskan agar membiarkan unta tersebut berkeliaran dan berkembang biak. Namun, Ustman ibn Affan menetapkan lain, yaitu agar unta yang hilang tersebut dijual sementara uangnya tetap disimpan. Jika suatu saat pemiliknya datang maka uang hasil penjualan tersebut diserahkan. Jika tidak maka uang tersebut digunakan untuk kepentingan umum. Utsman menetapkan demikian karena begitu banyaknya unta yang hilang dikhawatirkan menganggu kenyamanan masyarakat di sekitar, juga dikhawatirkan menimbulkann seseorang menjadi pencuri (Basiq Djalil, 2012: 144-145).

\section{PENUTUP}

Umar Ibn Khattab adalah profil seorang pemimpin yang sukses, mujtahid yang ulung dan sahabat Rasulullah yang sejati. Ia sukses dalam mengibarkan panjipanji Islam. Ia wafat dalam usia 63 tahun setelah kurang lebih 10 tahun mengenggam amanat sebagai khalifah hingga akhinya beliau terbunuh oleh salah seorang musuhnya yang bernama Abu Lu'lu'ah dengan cara yang amat tragis. Kepiawaian Umar dalam memimpin sangat energik dan strategik sehingga dapat menguasai semua medan wilayah penaklukan dan pengembangan Islam. Banyak tindakan Umar dalam bidang hukum seperti yang telah dikemukakan di atas, sepintas lalu keputusan-keputusan Umar itu seakanakan bertentangan dengan ketentuanketentuan Alquran, namun kalau dikaji sifat hakikat ayat-ayat tersebut dalam kerangka tujuan hukum Islam keseluruhannya, ijtihad yang dilakukan Umar ibn Khattab itu tidak bertentangan dengan maksud ayat-ayat hukum tersebut.

\section{DAFTAR KEPUSTAKAAN}

Al- Asyqar, Umar Sulaiman. 1991. Tarikh Al Figh Al Islami. Amman: Dar al Nafa'is.

Ali, Mohammad Daud. 2011. Hukum Islam: 
Pengantar Ilmu Hukum Dan Tata

Hukum Islam Di Indonesia. Jakarta: PT

Raja Grafindo Persada.

'Aliyah, Samir. 2004. Sistem Pemerintahan, Peradilan Dan Adat Dalam Islam. Jakarta: Khalifah.

Amin, Muhammad. 1991. Ijtihad Ibnu Taimiyah Dalam Bidang Figh Islam. Jakarta Timur: INIS.

Asrohah, Hanun. 2001. Sejarah Pendidikan Islam. Jakarta: Logos Wacana Ilmu.

Barkatullah, Abdul Halim. 2006. Hukum Islam: Menjawab Tantangan Zaman Yang Terus Berkembang. Jogjakarta: Pustaka Pelajar Offset.

Djalil, Basiq. 2012. Peradilan Islam. Jakarta: Amzah.

Djamil, Fathurrahman. 1997. Filsafat Hukum Islam. Jakarta: Logos Wacana Ilmu, cet 1 .

Fatmawati. 2010. Sejarah Peradaban Islam,. Batusangkar: STAIN Batusangkar Press, Jilid 1
Hart, Michael H. 2005. 100 Tokoh Paling Berpengaruh Sepanjang Masa. Kharisma Publishing Group.

Hasan, Ibrahim Hasan. 2002. Sejarah Kebudayaan Islam Diterjemahkan Oleh H.A. Bahauddin Judul Asli Tarikh Al Islam as Siyasi Wa as Tsaqafi Wa $\mathrm{Al}$ Ijtima. Jakarta: Kalam Mulia.

Hasbi. 1993. Falsafah Hukum Islam. Jakarta: Bulan Bintang, cet. IV

Koto, Alaiddin. 2011. Sejarah Peradilan Islam. Jakarta: PT Raja Grafindo Persada.

May, Asmal. 2015. Peradaban Islam Dalam Lintasan Sejarah. Jakarta: Citra Harta Prima.

Mubarok, Jaih. 2000. Sejarah Dan Perkembangan Hukum Islam. Bandung: Remaja Rosdakarya.

Syalabi, Ahmad. 2003. Sejarah Kebudayaan Islam 1. Jakarta: PT Al Husna Baru.

Syarifuddin, Amir. 1990. Pembaharuan Pemikiran Hukum Islam.. Padang: Angkasa Rayas, cet. 1 